\title{
Examining the Structural Relatiosnhips of Product Price, Product Quality and Customer Purchasing Decision
}

\author{
Angelina Ricardina Marcal, Estanislau de Sousa Saldanha, Alvaro Menezes Amaral \\ Graduate School-Master of Business Administration (MBA), Dili Institute of Technology (DIT), Timor-Leste \\ Email: ricardinaangelina@gmail.com, estanislausaldanha@yahoo.com,alvaromenezesamaral@gmail.com.
}

\begin{abstract}
This research aims to test the influence of price and product quality on customers' purchasing decision. To this, 105 respondents were used to fill up the questionnaires, Smart-PLS 3.0 was used to analyze and test the hypothesis. The results showed that product price influenced positively and significantly on customers' purchasing decision, while product quality did not. This research enriches the empirical study on price, product quality, and the customer purchasing decision. At the practical level, the result revealed that corporates should emphasis developing and delivering products meeting the needs of customers in price sensitive market in order to stimulate customer's purchasing decision and enhance corporate's market share.
\end{abstract}

Keywords: Price, product quality, purchasing decision.

\section{Introduction}

Increasing recent price and product competition require corporate to set up fair price and good product quality in order to stimulate customer purchasing decision. Therefore, many researches were carried out to understand which factors influence customer purchasing decisions. Customer purchasing decision depends on price, product quality and service quality. If a company provides good price, product quality, and service quality will meet customers' satisfactions (Philip and Keller, 2016; Kaswengi and Lambey-Checchin, 2019), which lead to purchase products/services (Anderson et al., 2000; Jung and Yoon, 2012; Maslowska et al., 2017; von Helversen et al., 2018). Therefore, companies seek to know customer specific needs in order to offer products/services based on these specific demands (Huang and Benyoucef, 2017). These customer's preferred purchasing consideration is often obtained via online information and words of mouths (WOM) (Cheung et al., 2014; Maslowska et al., 2017; Weisstein et al., 2017; Karimi et al., 2018).

The purchasing decision depends on the good and durable products (Kotler and Amstrong, 2012). To this, companies try to manufacture and offer products with high quality and brand in order to meet customer demands and enhance its competitiveness in the market. Therefore, product quality influence positively and significantly on customer satisfaction (Rua et al., 2020), which then lead to significantly impacts on customers' willingness to buy (Beneke et al., 2013). However, numerous empirical studies also revealed that product quality had no significant impacts on customers' purchasing decisions (Conti et al., 2019). This is particularly true for the emerging markets in which customers more sensitize on the product price than product quality (Baack and Boggs, 2008).
Product price generally as preferred option for consumers to buy any products/ services from a company (Asadi et al., 2014; Hustić and Gregurec, 2015), therefore price has significant effect on product value and costumer purchasing decision (Asadi et al., 2014; Papafotikas et al., 2014; Song et al., 2019; Zietsman et al., 2019; Carvalho et al., 2020; Hati et al., 2021). However, previous empirical studies also revealed that product price does not influence significantly consumer purchasing decision (Gok et al., 2019) or adverse impacts on purchasing decision (Kukar-Kinney et al., 2012). This particularly true when customers are merely sensitize to the product price compared to the product quality. Therefore, manufactures are trying to sell product with low cost in order to capture customer demand, aiming to increasing market share.

Product price, quality and customer purchasing decision are among well marketing variables that continuously gained interest from researchers to study in different market environmental settings. This is because previous empirical studies revealed that several inconsistencies of the results of the studies. Therefore, studies need to be carried out continuously, either within the measurement items or variable's relational models in different types of industries and market environment. This research aimed to contribute in this unsettled issue by looking at the specific attention on: (1) To identify the effect of price on the customers' purchasing, (2) to test and explain the influence of product quality on the consumer's purchasing decision. This is very important because so far there is no research on the relationship between price, product quality and consumers' purchasing. 


\section{Theoritical Framework, Conceptual Model and Hypotheis}

\subsection{Price}

Price is one of important factors which are trigger product competition. Price refers to an amount of money used to purchase any product or service (Zietsman et al., 2019). Price is the value of money exchanged with any product or service (Kotler and Amstrong, 2012). Price must be carefully determined and presented to customers in order to attract customers. Price should be fair in order to attract the customers to buy any product (Zietsman et al., 2019). Often companies provide price discount to encourage customers to purchase the products, aiming to enhance product's competitive position in the market. Price is usually influenced by quality, product value, quantity of product in the market, and the number of customers. The high price of any product shows the value or quality of the product itself (Vera, 2015). Price also depends on the supply and demands of the products in the market. The highest product demands, the highest of the price, or vice versa.

Numerous previous studies seek to find a better strategy to determine reasonable price of any products based on its quality (Nguyen and Meng, 2016). Such studies used different indicators which resulted in different findings. Some producers determine product price based on the standard that more fair, reasonable and acceptable by their customers (Cakici et al., 2019). In addition, Djatmiko and Pradana (2016) measured the product price with fair price, fix price, reliable price and relative price, while Boniface et al. (2012) measured product price by using price reliability, relative price, price-quality ratio, price fairness and price transparency.

\subsection{Product Quality}

Products are materials or prosperities available in the market to fulfill customer's needs and desire (Kotler and Amstrong, 2012). Kumar et al. (2011) as cited by Conti et al. (2019) defined product quality as a process of increasing productivity and decrease costs, which then lead to improve product competitiveness in the market and meet customer satisfaction. Quality of product often defined as condition of any product that last for long time, attractive, and qualified in accordance to agreeable standard (Cakici et al., 2019). Therefore, product quality influences product competitiveness in the market, which then ultimately influence company's competitiveness (Whang, 2017; Conti et al., 2019).

Product quality plays an important role according to the customers' perspective. Product performance which meets manufacturing standards and product-designed purpose will be used by the customers for product quality reference (Beneke et al., 2013).The good quality of product usually meets numerous measurements such as function, durable and not easily broken. The quality of product influenced by value, prestige, brand, type of products (Beneke and Zimmerman, 2014), fair perception and the quality of service (Zietsman et al., 2019), and customer value (Razak et al., 2017), ultimately satisfy customer's needs (Kaswengi and Lambey-Checchin, 2019). In addition, product certification often influences product quality (Cai et al., 2016) due to this is a proven action that the product has been gone through numerous stage in order to ensure the quality of the product meet at least quality, secure and effectiveness as its purpose designed.

Garvin (1988) as cited by Wang et al. (2003) presented eight dimensions to measure product quality such as performance, features, conformance, reliability, durability, serviceability, aesthetics, and customer-perceived quality. Rua et al. (2020) measured product quality by using four dimensions adapted from previous empirical studies namely conformance to specification (three items), durability (three items), design innovation and improvement (four items), and brand image (six items).

\subsection{Purchasing Decision}

Customers have many options to undertake product purchasing decision. In this case, such options play an important role in influencing the decision making. Hence, it is important for company not to ignore type and brand of the product as an especial identity that needed to be known by customers. Customers often internally searched for any information related to previous price of any product before looking for any information from other friends or outside (Maslowska et al., 2017). In other words, experiences of purchasing any products in the past are considered to be source of internal information to grant any good decision (Cheung et al., 2014).

Some empirical studies also highlighted that in making purchasing-decision, the customers always find the way to minimize the risk. The purchasing/buying- decision is the customers' choices to be made to whether or not to purchase/buy any products based to various factors (Kotler and Keller, 2012). There are five (5) steps in making decision such as: searching for the problem, searching for the information, assessing the alternatives, after purchasing and assessing the performance (Karimi et al., 2018).

Purchasing decision involves number of elements which formulated by customers before purchasing or buying any products in fulfilling the customers' needs. Customers should reach an agreement on venue of selling, desired-brand of product, model, quantity, time spent, amount of money to be spent, and other factors that influenced the decision. The Decision taking, indeed, influenced the Market through information spread on the product and service which has to be figured out by the customers (Hanaysha, 2018). 


\subsection{Conceptual Framework}

Product quality and price influence corporate performance. A customers' purchasing decision on any product or service can increase the market share that implies to the company's profitability. With such thought, this research depends to the customers' decision with its previous variables such as the quality of products and price. This research model was developed based on empirical studies from (Nguyen and Meng, 2016), Zietsman et al. (2019) for the product price, Beneke \& Zimmerman (2014), and Veloutsou (2015) for product quality, and Kotler \& Keller (2012) for purchasing decision.

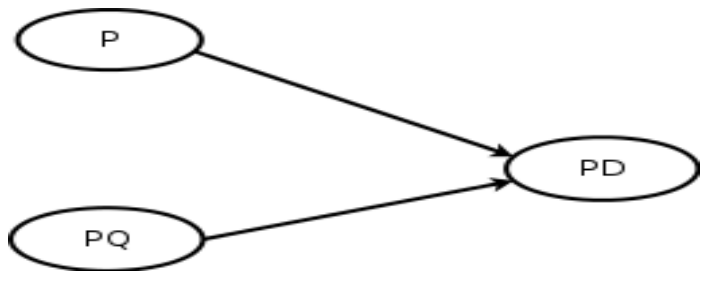

Figure 1. Concept Framework of Research $(P=$ Price; $P Q=$ Product Quality; and PD=Purchasing Decision).

\section{Hypothesis}

Price is the value of money exchanged with any product or service (Kotler and Amstrong, 2012). Price is an important factor for the purchasers to make a decision on whether or not to purchase the referred products. This is because the purchasers have to figure out the balance and the value between the price and product performance (quality of the product) that they have before buying them (Voss et al., 1998). Many studies have shown that price influence positively and significantly on the customer's purchasingdecision (Asadi et al., 2014; Papafotikas et al., 2014; Song et al., 2019; Zietsman et al., 2019; Carvalho et al., 2020; Hati et al., 2021). Therefore, hypothesis of this study will be as follow:

$\mathrm{H}_{1}$ : Price influence positively and significantly on the purchasing-decision.

The product quality and brand are important factors for customer's consideration before they decide to purchase a product (Belz \& Peattie, 2009; Kotler, 2003:224). Therefore, product quality influence positively and significantly on customer satisfaction (Rua et al., 2020), which then lead to significantly impacts on customers' willingness to buy (Beneke et al., 2013). To this, the hypothesis can be formulated as follow:

$\mathrm{H}_{2}$ : Product quality positively and significantly influences on the purchasing decision.

\section{Research Methods}

This research was carried out in $\mathrm{H}_{2} \mathrm{O}$ Company, Dili Timor-Leste from January to March 2020 which involved 144 customers listed in the database of $\mathrm{H}_{2} \mathrm{O}$ Company. Due to small size, all population was selected as respondents.

Data collection used questionnaire adopted from (Nguyen and Meng, 2016), (Zietsman, Mostert and Svensson, 2019) for product price, (Beneke and Zimmerman, 2014), Veloutsou (2015) for product quality, and Kotler \& Keller (2012: 188) for Purchasing-Decision. The questionnaire of this study used 5 Scale Likert starting from 1 (Strongly Disagree) to 5 (Strongly Agree). In this research, 144 questionnaires were distributed, but only 105 questionnaires were returned, and valid to be used, which give the survey response rate of $72.9 \%$.

Smart-PLS 3.0 was used to test hypothesis because it can be used for small sample size, reflective/formative indicator, multivariate test, and no need for data normality and collinearity test (Hair et al., 2014; Saldanha et al., 2018). Outer model measurement was tested by using composite reliability (CR) and Cronbach Alpha (CA). An item is reliable when the $\mathrm{CR}$ and $\mathrm{CA}$ values is greater than 0.7 (Hair et al., 2014; Saldanha et al., 2018). The validity test distributed in two convergent validities (outer loading or indicator loading and average variance extracted or AVE). The discriminant validity (Fornell-larker, Cross load, with Heterotrait-Monotrait). The indicator is valid in Convergent Validity when the value of Outer Loading (OL) is greater than 0.7, and the value of Average Variance Extracted (AVE) is greater than 0.5 (Hair et al., 2014, Hair et el., 2017; Saldanha, 2019). Validity is figured out from the perspective of discriminant validity. An indicator is valid when it has a value of root of AVE to other indicators and greater with its value greater than the value of other indicators (Hair et al., 2014), and the Heterotrait-monotrait (HTMT) is lower than 0.85 (Henseler et al., 2015). After testing the validity and reliability of the model, the next step is to test the significance of the relationship between variable (inner model measurement). The relation between variables are considered significant when the $\mathrm{T}$ value is greater than 1.96, and $\mathrm{P}$ value is lower than 0.05 (Hair et al., 2017; Saldanha et al., 2019).

\section{Results}

\subsection{Demographical Characteristics of Respondents}

The total of respondents of this research is 105 consumers of the H2O Company, Dili. The percentage of male was $66.7 \%$ and female was $33.3 \%$ as describe in Table I. Hence, male still dominant among all consumers in this $\mathrm{H} 2 \mathrm{O}$ Company which means that to purchase the water which is heavy still dominated by male as it is related to heavy things. 
Viewing from the education level, majority of the respondents are Secondary School Graduates with $65.7 \%$ and Diploma is $20 \%$, and first degree (Bachelor level) is $11.4 \%$. from civil study, majority of consumers of $\mathrm{H} 2 \mathrm{O}$ Company are married couples with $87.6 \%$ compared to single one with $12.4 \%$ as shown in Table I. this indicated that majority of consumers of $\mathrm{H} 2 \mathrm{O}$ Company are married people who bought water of house consume and related to house activities.

Table I. Demographical Characteristics of Respondents seeing from perspective of Gender, Level of Education, and Civil Study.

\begin{tabular}{|lclc|}
\hline \multicolumn{1}{|c}{ Gender } & $\boldsymbol{\%}$ & \multicolumn{1}{c}{ Level of Education } & $\%$ \\
\hline Male & 66.7 & Secondary School & 65.7 \\
\hline Female & 33.3 & Diploma. & 20.0 \\
\hline Total & $100 \%$ & & 11.4 \\
\hline Civil Study & $\%$ & 1st Degree & 2.9 \\
\hline Single & 12.4 & Master Degree & \\
\hline Married & 87.6 & & $100 \%$ \\
\hline Total & $100 \%$ & Total & \\
\hline
\end{tabular}

\subsection{Loading Factor Analysis}

Before testing the validity and reliability, confirmatory analysis was firstly run. Then loading factor that is lower than 0.5 was eliminated in order to increase the acceptable threshold values of Outer Loading (OL) and Average Variance Extracted (AVE) as recommended by Hair et al. (2014). Therefore, PI, and P2 were eliminated in this model in order to increase OL and AVE values as shown Figure 1.

\subsection{Construct of Validity and Reliability Test \\ 4.3.1. Validity test}

Validity Test was divided into convergent and discriminant validity. Convergent Validity was using Outer Loading (OL) and Average Variance Extracted (AVE). Discriminant Test validity used parameter of FornellLarcker criterion (FL) (Hair et al., 2014) and HeterotraitMonotrait (HTMT) (Henseler et al., 2015).

\subsubsection{Convergent Validity}

Convergent validity used parameter Outer Loading (OL) and average Variance Extracted (AVE). An indicator has a value when the value of OL indicator is greater than 0.7, and the value of AVE is greater than 0.5 (Hair et al., 2014 and Hair et al., 2017). In this research, there were two indicators from the beginning such as P1, and P2 with its indicator loading is smaller than 0.4 , hence, according to Hair et al. (2014), these indicators should be eliminated from the model to avoid any influence on the content of validity and reliability. Figure 2 showed that the value of OL is greater than 0.7 which means all indicators a valid, expansion is PQ6 with PD1 with its value smaller than 0.7 but greater than 0.5. As this research is explorative, according to Hair et al. (2014), the value of OL can reach 0.6, and when it did not influence the content of validity and reliability, valor of OL indicator can be continuously used. Otherwise the value of OL is smaller than 0.4 which the indicator should be absolutely removed from the model.

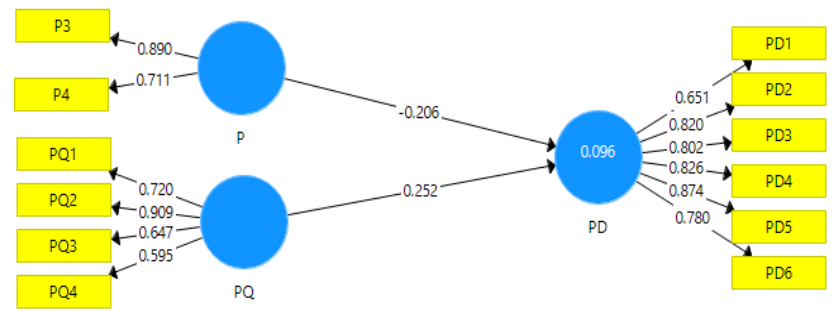

Figure 1. Outer Loading for Convergent Validity Tests.

It is seen from the Convergent Validity that measured by using parameter of AVE whose value is greater than 0.5 . In table IV shows that the value of AVE indicator also greater than 0.5 (Hair et al., 2017). Therefore all indicators are valid to test the inner model. 


\subsubsection{Discriminant Validity}

Discriminant Validity used the parameter of FornellLarcker (FL) Criteria and Heterotrait-Monotrait (HTMT). From the value of FL, Table II shows that the values of all items are greater than the minimum value that allowed by Hair et al. (2017). So, if we see from the value of FL, all indicators are valid to test the inner model.

Table II. The Value of Fornell-larcker Criterio for Discriminant Validity

\begin{tabular}{|c|c|c|c|}
\hline Item & P & PD & PQ \\
\hline $\mathbf{P}$ & 0,806 & & \\
\hline PD & 0,182 & 0,795 & \\
\hline PQ & 0,095 & 0,233 & 0,728 \\
\hline
\end{tabular}

The discriminant validity was tested using HTMT. Table III shows values of HTMT is lower than 0.81 , which means all items are valid in testing the inner model (Henseler, Ringle and Sarstedt, 2015).

Table III. The Value of Heterotrait-monotrait (HTMT) for Discriminant Validity

\begin{tabular}{|c|l|l|l|}
\hline & P & PD & PQ \\
\hline P & & & \\
\hline PD & 0,254 & & \\
\hline PQ & 0,212 & 0,225 & \\
\hline
\end{tabular}

\subsubsection{Reliability Test}

Reliability Test normally used Cronbach's Alpha (CA) and composite reliability (CR) (Hair et al., 2014; Hair et al., 2017). Table IV shows the values of CA and CR of all items are greater than the minimum threshold value of 0.6 respectively as recommended by Hair et al. (2014). Therefore, all items were reliable to test the inner model.

Table IV. Results of Reliability and Validity Test

\begin{tabular}{|c|c|c|c|}
\hline Item & CA & CR & AVE \\
\hline $\mathbf{P}$ & 0,676 & 0,785 & 0,649 \\
\hline PD & 0,883 & 0,911 & 0,632 \\
\hline PQ & 0,754 & 0,814 & 0,529 \\
\hline
\end{tabular}

\subsection{Hypothesis Test}

First hypothesis is to test the influence of price $(\mathrm{P})$ on purchasing decision (PD). The result of the test revealed that the $\mathrm{T}$ value (2.240) which is above the minimum allowable value of 1.96 and the $P$ value $(0.026)$ is lower than the maximum threshold value of 0.05 . This means that price $(\mathrm{P})$ influences positively and significantly on purchasing decision (PD). Therefore, $\mathrm{H}_{1}$ is supported.

The second hypothesis is to test the influence of product quality (PQ) on purchasing decision (PD). The result of this study shows in Table 4.8 that the Quality of Product did not significantly influence the Customers' Purchasing-Decision (PD). Therefore, when the quality of product is increased did not significantly influence the customers' purchasingdecision (PD). In short, when the quality of product is increased did not significantly increase the customers' purchasing decision. Therefore, $\mathrm{H}_{2}$ was rejected.

\section{Discussion}

The first objective of this research is to test the influence of Price $(\mathrm{P})$ on the Purchasing-Decision (PD). The result of the research showed that Price $(\mathrm{P})$ did influence positively and significantly on the consumers' PurchasingDecision (PD). Hence it showed that when the price is acceptable (P3) with discount (P4) will motivate consumers to purchase the product or obtain any service. That's why; price sometimes has negative relationship with the consumers' purchasing-decision (Son and Jin, 2019). It also means that if the price is increased, it will also influence the will of consumers to spend their money to purchase any products or obtain any service. On the other hand, if the price is low, might mean that it has low quality, but not reflected to the materials with high quality (Beneke et al., 2013). This was supported by many previous researches which showed the perception of quality decrease when it has low price (Devecchio and Puligadda, 2010).

The results of the study also confirm that the price is an important factor for the consumers purchasing-decision making whether or not to buy any products or obtain any services from any company (Voss et al., 1998). Low prices are also a motivation for the customers to buy the products or obtain any service and even the customers can extend the information for others in order to buy the product or obtain the service (Cakici et al., 2019). Good and fair price can become a reason to give a satisfaction for any customers and finally to maintain the loyalty of customers to purchase any products or service (Asadi et al., 2014).

The results of this study confirmed the result of previous researches that price did have influence but did not significantly influence to the customers' purchasingdecision. If the price is low, also, did not influence the customers to buy the products or obtain any service (Son and Jin, 2019). However, the results of this research also showed that the price negatively influenced the customers' 
Table V. The Results of Path Coefficient Test for Hypotehsis Test

\begin{tabular}{|c|c|c|c|c|c|c|}
\hline Relationship & $\begin{array}{c}\text { Original } \\
\text { Sample } \\
(\mathbf{O})\end{array}$ & $\begin{array}{c}\text { Sample } \\
\text { Mean } \\
(\mathbf{M})\end{array}$ & $\begin{array}{c}\text { Standard } \\
\text { Deviation } \\
\text { (STDEV) }\end{array}$ & $\begin{array}{c}\text { T Statistics } \\
(\mid \mathbf{O} / \text { STDEV|) }\end{array}$ & $\begin{array}{c}\text { P } \\
\text { Values }\end{array}$ & Note \\
\hline P -> PD & 0,206 & 0,216 & 0,092 & 2,240 & 0,026 & Significant \\
\hline PQ -> PD & 0,252 & 0,275 & 0,160 & 1,581 & 0,115 & Not Significant \\
\hline
\end{tabular}

purchasing-decision. Another reason is that when price increase will decrease the motivation of customers to purchase.

The second objective of research is to test the influence of of quality of product (PQ) on the customers' Purchasing-Decision (PD). The result of this study showed that the quality of product (QP) did not influence the Customers' Purchasing-Decision (PD). This might mean that if there was a increase of quality, it did not increase the motivation of customers to purchase the products. The factor that did influence insignificantly the relation between the quality of product and the Customers' Purchasing-Decision is good reputation (PQ4) and Good Quality (GQ1). The result confirmed that some pervious empirical studies presented that the quality of product did not have any relationship with the customers' will to buy any product or to obtain any services (Vera, 2015). It explained that in many countries with low income, the customers were very sensitive to purchase any cheap product comparing to the product with high quality. The research asymmetric (in line) with the result of previous researches that showed the quality of product can increase the value of customers the might end up with increase the motivation of customers to buy products or obtain services (Beneke et al., 2013).

\section{Conclusion and Implication}

Price, product quality and customers purchasing decision are important factors for marketing. Therefore, the academia and practitioners tried their best to integrate the three variables together to increase the competition and sustainability of a company. The result of this research showed that the price positively and significantly influenced the Customers Purchasing-Decision. Hence, when the price is good which manifested by the accessible price and discount will motivate the customers to purchase any product or obtain any services. The result of research also showed that the quality of product did not significantly influence the purchasing-decision of customers. It means that when the price is increased or decreased will not affect the customers' purchasing-decision.

This research aimed merely to observe the purchasing decision and its background. In the contrary, it is important to ensure the competitiveness and performance of the company. Therefore, it a need to pay attention more on the effect of mediation of customers purchasing-decision, competitiveness, and performance of the company as a bench mark or barometer for the profitability and sustainability of the company. The result of this research showed that, in fact, the price did have significant influence on customers purchasing-decision which implied to company manager to see the quality of service, the combination of product quality and the price in order to stimulate the customers' desire to purchase the product or obtain any services from the company.

\section{Limitation and Future Research}

This research aimed to test the relationship between the price and the quality of the product on the customer's purchasing-decision. The test results showed that price influenced significantly on purchasing decision, while product quality had adverse effect. This research has numerous limitations:

(1) The result of the research showed that the quality of product did not significantly influence to the customers' purchasing-decision. This might mean that the variable of quality of product did not influence the decision of customers to consume or not, but it might be other variables such as quality of service, innovative products, and any new products that oriented to market. (2) This research used 105 sample which was classified as a small sample. Such small sample could give significant influence among variables. (3) In This research, questionnaires were the instrument used for data collection. Therefore, whatever response from the respondents could be bias. This is to ensure the response can be accepted, although sometimes did not reflect the reality. Such bias might happen due to the lack of other instruments that the writer might use to validate all the answers from respondents. Hence, it is expected that the future researches can use other instruments such as interview, observation, group discussion to find qualitative data in order to confirm any research-results that were not significant.

\section{References}

Anderson, J. C., Thomson, J. B. L. and Wynstra, F. (2000) 'Combining value and price to make purchase decisions in business markets', International Journal of Research in Marketing, 17(4), pp. 307-329. 
Vol.2, Issue.2, pp.1-9, 2020

Available online at: https://tljbm.org/jurnal/index.php/tljbm

Asadi, A., Pool, J. K. and Jalilvand, M. R. (2014) 'The effect of perceived price fairness through satisfaction and loyalty on international tourists' price acceptance of Islamic-Iranian art products', Education, Business and Society: Contemporary Middle Eastern Issues, 7(4), pp. 201-215.

Baack, D. W. and Boggs, D. J. (2008) 'The difficulties in using a cost leadership strategy in emerging markets', International Journal of Emerging Markets, 3(2), pp. 125-139.

Beneke, J. et al. (2013) 'The influence of perceived product quality, relative price and risk on customer value and willingness to buy: A study of private label merchandise', Journal of Product and Brand Management, 22(3), pp. 218-228.

Beneke, J. and Zimmerman, N. (2014) 'Beyond private label panache: The effect of store image and perceived price on brand prestige', Journal of Consumer Marketing, 31(4), pp. 301-311.

Boniface, B., Gyau, A. and Stringer, R. (2012) 'Linking price satisfaction and business performance in Malaysia's dairy industry', Asia Pacific Journal of Marketing and Logistics, 24(2), pp. 288-304.

Cai, R., Ma, W. and Su, Y. (2016) 'Effects of member size and selective incentives of agricultural cooperatives on product quality', British Food Journal, 118(4), pp. 858-870.

Cakici, A. C., Akgunduz, Y. and Yildirim, O. (2019) 'The impact of perceived price justice and satisfaction on loyalty: the mediating effect of revisit intention', Tourism Review, 74(3), pp. 443-462.

Carvalho, H. de F., Saldanha, E. de S. and Amaral, A. M. (2020) 'The Mediation Effects of Customer Satisfaction on the Relations Between Product Price, Service Quality and Purchasing Decision', Timor-Leste Journal of Business and Management, 2(1), pp. 14-26.

Cheung, C. M. K., Xiao, B. S. and Liu, I. L. B. (2014) 'Do actions speak louder than voices? the signaling role of social information cues in influencing consumer purchase decisions', Decision Support Systems, 65(C), pp. 50-58.

Conti, E. et al. (2019) 'Design-driven innovation, quality, and customer value in manufacturing companies', TQM Journal, 31(6), pp. $968-986$.

Djatmiko, T. and Pradana, R. (2016) 'Brand Image and Product Price; Its Impact for Samsung Smartphone Purchasing Decision', Procedia - Social and Behavioral Sciences, pp. 221-227.

Gök, O., Ersoy, P., \& Börühan, G. (2019). The effect of user manual quality on customer satisfaction: the mediating effect of perceived product quality. Journal of Product and Brand Management.

Hair, J., Hollingsworth, C. L., Randolph, A. B., \& Chong, A. Y. L. (2017). An updated and expanded assessment of PLS-SEM in information systems research. Industrial Management \& Data Systems, 117(3), 442-458.

Hair, Joe F., Sarstedt, M., Hopkins, L., \& Kuppelwieser, V. G. (2014). Partial least squares structural equation modeling (PLSSEM). European Business Review, 26(2), 106-121.

Hanaysha, Jalal Rajeh. 2018. "An Examination of the Factors
Affecting Consumer's Purchase Decision in the Malaysian Retail Market.” PSU Research Review 2 (1): 7-23.

von Helversen, B. et al. (2018) 'Influence of consumer reviews on online purchasing decisions in older and younger adults', Decision Support Systems, 113(March), pp. 1-10.

Henseler, J., Ringle, C. M. and Sarstedt, M. (2015) 'A new criterion for assessing discriminant validity in variance-based structural equation modeling', Journal of the Academy of Marketing Science, 43(1), pp. 115-135.

Huang, Z. and Benyoucef, M. (2017) 'The effects of social commerce design on consumer purchase decision-making: An empirical study', Electronic Commerce Research and Applications, 25 , pp. $40-58$

Hustić, I. and Gregurec, I. (2015) 'The influence of price on customer's purchase decision', Central European Conference on Information and Intelligent Systems, pp. 1-6.

Jung, H. S. and Yoon, H. H. (2012) 'Why do satisfied customers switch? Focus on the restaurant patron variety-seeking orientation and purchase decision involvement', International Journal of Hospitality Management, 31(3), pp. 875-884.

Karimi, S., Holland, C. P. and Papamichail, K. N. (2018) 'The impact of consumer archetypes on online purchase decision-making processes and outcomes: A behavioural process perspective', Journal of Business Research, 91(June), pp. 71-82.

Kaswengi, J. and Lambey-Checchin, C. (2019) 'How logistics service quality and product quality matter in the retailer-customer relationship of food drive-throughs: The role of perceived convenience', International Journal of Physical Distribution and Logistics Management.

Kotler, P. and Amstrong, G. (2012) Principles of Marketing. 14th edn. New Jersey: Prentice Hall.

Kukar-Kinney, M., Ridgway, N. M. and Monroe, K. B. (2012) 'The Role of Price in the Behavior and Purchase Decisions of Compulsive Buyers', Journal of Retailing, pp. 63-71.

Maslowska, E., Malthouse, E. C. and Viswanathan, V. (2017) 'Do customer reviews drive purchase decisions? The moderating roles of review exposure and price', Decision Support Systems, pp. 1-9.

Nguyen, A. and Meng, J. G. (2016) 'How source of funds affects buyer's judgments of price fairness and subsequent response', Journal of Product and Brand Management, 25(7), pp. 710-720.

Papafotikas, I., Chatzoudes, D. and Kamenidou, I. (2014) 'Purchase Decisions of Greek Consumers: An Empirical Study', Procedia Economics and Finance, 9(14), pp. 456-465.

Philip, K. and Keller, K. L. (2016) Marketing Management. 15th Editi. Boston: Pearson.

Razak, I., Nirwanto, N. and Triatmanto, B. (2017) 'The Impact of Product Quality and Price on Customer Satisfaction with the Mediator of Customer Value Ismail', Journal of Marketing and Consumer Research, 3(11), pp. 1240-1248. 
Rua, S., Saldanha, E. de S. and Amaral, A. M. (2020) 'Examining the Relationships among Product Quality, Customer Satisfaction and Loyalty in the Bamboo Institute, Dili, Timor-Leste.pdf', TimorLeste Journal of Business and Management, 2(1), pp. 33-44.

Saldanha, E. de S., Rahyuda, I. K., Yasa, N. N. K., \& Sukaatmadja, I. P. G. (2018). The Role of Business Strategy in Mediating the Relationship Between Industrial Competition and Performances : A Study in the Higher Education Industry in Timor-Leste. European Jorunal of Business and Management, 10(8), 152-172.

Saldanha, E. de S. (2019) 'The Mediation Effects of Business Strategy on the Relations between Industrial Competition and Performance', Timor-Leste Journal of Business and Management, 1(1), pp. 1-11.

Song, M., Lee, W. S. and Moon, J. (2019) 'Exploring effective price presentation format to reduce decision difficulty and increase decision satisfaction', Tourism Management Perspectives.

Veloutsou, C. (2015). Brand evaluation, satisfaction and trust as predictors of brand loyalty: the mediator-moderator effect of brand relationships. Journal of Consumer Marketing, 32(6), 405421.

Vera, J. (2015) 'Perceived brand quality as a way to superior customer perceived value crossing by moderating effects', Journal of Product and Brand Management, 24(2), pp. 147-156.

Wang, Y., Lo, H. P. and Hui, Y. V. (2003) 'The antecedents of service quality and product quality and their influences on bank reputation: Evidence from the banking industry in China', Managing Service Quality: An International Journal, 13(1), pp. 7283.

Weisstein, F. L. et al. (2017) 'Examining impacts of negative reviews and purchase goals on consumer purchase decision', Journal of Retailing and Consumer Services, 39(July), pp. 201-207.

Whang, U. (2017) 'Comparative advantage, product quality, and the competitiveness of firms', Journal of Korea Trade, 21(3), pp. 174-190.

Zietsman, M. L., Mostert, P. and Svensson, G. (2019) 'Perceived price and service quality as mediators between price fairness and perceived value in business banking relationships: A microenterprise perspective', International Journal of Bank Marketing, 37(1), pp. 2-19. 
Vol.2, Issue.2, pp.1-9, 2020

\section{Appendix. Data Collection Instrument}

I. Price

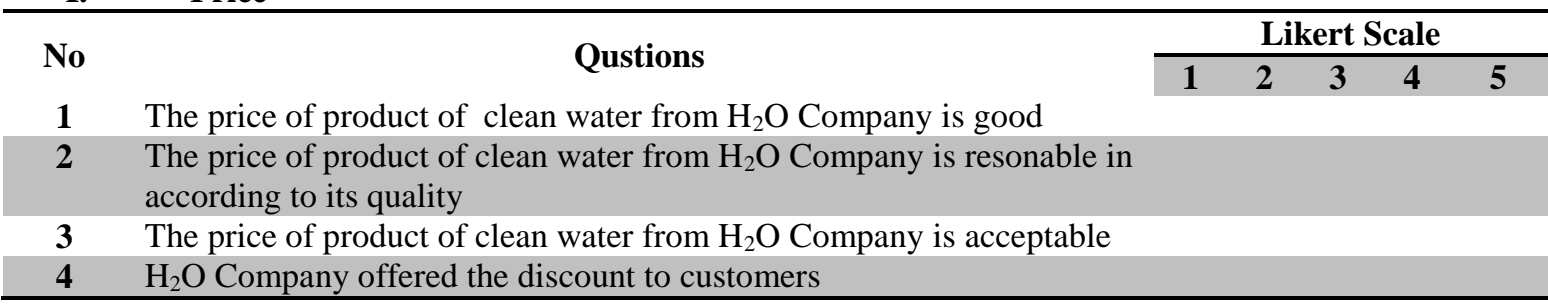

II. Product Quality

\begin{tabular}{cll}
\hline No & \multicolumn{1}{c}{ Questions } & \multicolumn{2}{c}{ Likert Scale } \\
\cline { 2 - 3 } $\mathbf{1}$ & $\begin{array}{l}\text { Product of potable water from } \mathrm{H}_{2} \mathrm{O} \text { company is in line with my preferred } \\
\text { desire }\end{array}$ & \\
$\mathbf{2}$ & $\begin{array}{l}\text { The Duration of the Product of potable water from H2O Company is in } \\
\text { line wiht the standar that I preferred. }\end{array}$ \\
$\mathbf{3}$ & $\begin{array}{l}\text { The Product of the potable water from } \mathrm{H} 2 \mathrm{O} \text { Company is good and } \\
\text { healthy according to my preference }\end{array}$ \\
$\mathbf{4}$ & $\begin{array}{l}\text { Product of portable and clean water from H2O Company has good a } \\
\text { reputation. }\end{array}$ \\
\hline
\end{tabular}

\section{Purchasing Decision}

\begin{tabular}{|c|c|c|c|c|c|c|}
\hline \multirow{2}{*}{ No } & \multirow{2}{*}{ Questions } & \multicolumn{5}{|c|}{ Likert Scale } \\
\hline & & 1 & 2 & 3 & 4 & 5 \\
\hline 1 & I decided to purchase water from $\mathrm{H} 2 \mathrm{O}$ Company due to its price & & & & & \\
\hline 2 & I decided to purchase water from $\mathrm{H} 2 \mathrm{O}$ Company due to its quality & & & & & \\
\hline 3 & $\begin{array}{l}\text { I decided to purchase water from } \mathrm{H} 2 \mathrm{O} \text { Company due to its quality of } \\
\text { service }\end{array}$ & & & & & \\
\hline 4 & $\begin{array}{l}\text { I decide to purchase water from } \mathrm{H} 2 \mathrm{O} \text { Company due to words of mouth } \\
\text { marketing (WOM). }\end{array}$ & & & & & \\
\hline 5 & $\begin{array}{l}\text { I decide to purchase water from } \mathrm{H} 2 \mathrm{O} \text { Company due to my own } \\
\text { experience }\end{array}$ & & & & & \\
\hline 6 & I decided to purchase water from $\mathrm{H} 2 \mathrm{O}$ Company due to its brand. & & & & & \\
\hline
\end{tabular}

